\title{
Potential Use of Natural Red Mud as Pozzolan for Portland Cement
}

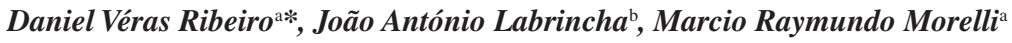 \\ ${ }^{a}$ Department of Materials Engineering, Federal University of São Carlos, \\ Rod. Washington Luis, Km 235, CEP 13566-550, São Carlos, SP, Brazil \\ ${ }^{\mathrm{b}}$ Ceramics and Glass Engineering Dept., University of Aveiro \& CICECO, \\ Campus Universitário de Santiago, CEP 3810-193, Aveiro, Portugal
}

Received: October 12, 2010; Revised: December 22, 2010

\begin{abstract}
Red mud, the main waste generated in aluminum and alumina production by the Bayer process, is considered hazardous due to its high pH, according to the Brazilian standard NBR 10004/2004, and worldwide generation of this waste exceeds 117 million tons/year. In this work, non-calcined red mud was used, thus requiring less energy and time and reducing costs, which is the ideal condition for reusing wastes. Mortars containing $30 \mathrm{wt}$. (\%) of cement substituted by red mud showed higher strength of hardened products. The pozzolanic activity index was evaluated based on physical and mechanical parameters (Brazilian NBR 5751 and NBR 5752 standards) and on a chemical analysis (European EN 196-5 standard). A comparison of the reference mixture (without red mud) and the results obtained with red mud confirm the potential of non-calcined red mud for use a as pozzolanic additive in cementitious materials. The setting time (according to the MERCOSUL NM 65 standard) tends to increase but workability remains almost unchanged.
\end{abstract}

Keywords: Cement mortars, red mud, setting time, pozzolanic activity

\section{Introduction}

Replacing natural raw materials with wastes may offer a much sought after opportunity to mitigate today's waste management problems. Even if this is done in small amounts, high production rates will translate into significant consumption of waste materials and, for the industry willing to use them, the latter may constitute a cheap and renewable source of raw materials ${ }^{1}$. In this context, upgrading industrial wastes to alternative raw materials is both technically and economically advantageous for a wide range of applications ${ }^{2}$, including the fabrication of concretes and mortars ${ }^{3}$. In recent years, several studies have confirmed the potential of civil construction as a suitable recipient of various types of recycled wastes, which are now considered secondary raw materials ${ }^{4-7}$.

Red mud is the main waste generated in the production of aluminium and alumina by the Bayer process from bauxite ore. The world's production of bauxite in 2009 was 205 million tons, and the main producing countries were Australia, China, Brazil, Guinea, India and Jamaica. Ranking third in worldwide production in 2009, Brazil produced 26.6 million tons of bauxite. It also has the world's third largest bauxite ore reserves (around 3.5 billion tons), concentrated mainly in the northern part of the country (State of Pará) ${ }^{6}$. Roughly $0.3-1.0$ tons of red mud waste are generated per ton of aluminum produced. Brazil has discarded about 10.6 million tons/year of caustic red mud in recent years and the worldwide generation of red mud exceeds 117 million tons/year ${ }^{7}$.

Red mud is usually discharged as highly alkaline slurry ( $\mathrm{pH} \mathrm{10-13.5)} \mathrm{with} 15-40 \%$ solids, which is pumped away for suitable disposal. Its chemical and mineralogical composition may change temporarily, depending on the source of bauxite and on the technological processing conditions. Red mud is composed of six major oxides: $\mathrm{Al}_{2} \mathrm{O}_{3}, \mathrm{Fe}_{2} \mathrm{O}_{3}, \mathrm{Na}_{2} \mathrm{O}, \mathrm{SiO}_{2}, \mathrm{CaO}$, and $\mathrm{TiO}_{2}$, and a large variety of minor elements. Due to its strong alkalinity $\left(\mathrm{Na}_{2} \mathrm{O}+\mathrm{NaOH}=2.0-20.0\right.$ wt. $\left.(\%)\right)$, the conditions in which it can be discarded are restricted to minimize environmental problems such as soil contamination and groundwater pollution.

Alkaline matrices such as those provided by Portland cement in mortars and concrete are commonly used in waste conditioning. They are inexpensive, have an extensively documented history of safe use, and are a draw-upon readily-accessible technology. Alkalinity greatly reduces the solubility of many hazardous inorganic species and inhibits microbiological processes. Moreover, since these matrices require water for hydration, they may readily incorporate wet wastes ${ }^{8}$ such as red mud.

The search for an economically and environmentally viable alternative has led to the study of red mud for various applications, such as alternative construction material ${ }^{9,10}$, an adsorbent for the removal of heavy metals from aqueous solutions ${ }^{11}$, building materials such as bricks ${ }^{12,13}$, ceramics and tiles ${ }^{14}$, ceramic glazes ${ }^{15}$ and iron-rich cement $^{9,16}$. However, most of the studies cited here used high temperatures to improve the properties of red mud.

This paper reports on a study of the influence of the addition of red mud on the characteristics of cement mortars without previous calcination treatment, requiring less energy and time and reducing costs in terms of setting time, pozzolanic activity and changes in mechanical strength.

Dow and Glasser ${ }^{17}$ showed that the amount of $\mathrm{SiO}_{2}$ and $\mathrm{Al}_{2} \mathrm{O}_{3}$ in red mud may be decisive to increase its cementitious activity. Furthermore, other researchers ${ }^{13}$ found that the hydration reaction of Portland cement is favored by a highly alkaline environment, which is a characteristic of red mud.

About half of the amount of Portland cement consumed in building construction is used in masonry and plastering. In those products, the maximum potential strength developed by the cement is never fully utilized. In fact, strength requirements for such applications are in the order of $4.0 \mathrm{MPa}$, while Portland cement is ideally suited 
for applications with strength requirements exceeding $15.0 \mathrm{MPa}^{18}$. Materials with pozzolanic characteristics may thus partially replace the cement in those applications, and red mud is tested here for this purpose, as suggested elsewhere ${ }^{18-21}$.

\section{Experimental}

\subsection{Materials}

Ordinary CP-II 32 Z Portland cement (OPC), according to the Brazilian NBR 11578 standard, commercially available in São Carlos, Brazil, was selected as reference in all the tests. Its characterization involved X-ray diffraction (Rigaku Geirgeflex ME 210GF2 Diffractometer) and X-ray fluorescence (Philips PW1480 X-ray Fluorescence Spectrometer) analyses, while physical parameters such as the specific surface area (estimated by BET, using a Micrometrics Gemini 2370 V1.02 equipment) and specific gravity (Helium Pycnometer Accupyc 1330 V2.01 from Micrometrics) were also determined. Similar determinations were performed on sand and on the red mud.

The sand was supplied from a river deposit commercially available in São Carlos, Brazil. The red mud came from Poços de Caldas-MG and was supplied by ALCOA Brazil. It is a mixture containing about $60 \%$ of solids, collected immediately after alumina recovery from the digestion process.

\subsection{Methods}

The mortar formulation used as reference was prepared in a 1.0:3.0:0.60 (cement:sand:water) weight ratio. Distinct mortars in which cement was partially replaced by red mud (up to $50 \%$ in weight) were analyzed.

The setting time was determined by the Vicat needle method, according to the MERCOSUL NM 65 standard (Portland Cement Determination of Setting Times). Mixtures with water were prepared to obtain a paste of "normal consistency" (NM 43:2002 standard). A conical mold was filled with the paste, which was penetrated by the Vicat needle at time intervals established by the standard. The moment when the needle reaches a depth of $4 \pm 1 \mathrm{~mm}$ from the base defines the beginning of setting. Setting is complete when the needle penetrates to a depth of only $0.5 \mathrm{~mm}$ from the top. The time interval between these two moments defines the workability window of the mortar.

The reference mortar formulation was prepared with a ratio of $1: 3$ (cement:sand) and 0.57 water:cement, which was the water content required to obtain the paste with a "normal consistency."

The pozzolanic activity of the red mud was evaluated by determining the physical and chemical parameters of the mixtures according to the Brazilian standards NBR 5751 (Determination of pozzolanic activity - Index with lime) and NBR 5752 (Determination of pozzolanic activity with Portland cement). In the first method (NBR 5751), mixtures of the material under evaluation containing calcium hydroxide (lime) and sand were prepared and molded. The NBR 5752 standard requires testing two distinct mortar formulations: (i) mortar "A" containing Portland cement as the single binder and (ii) mortar "B" prepared by replacing (35 wt. (\%)) of Portland cement by the pozzolanic material (red mud, in this case).

Table 1 summarizes the conditions used in the preparation of the mixtures. In this table, "w", "x" and " $y$ " values represent the amount of water required to produce mortars with a consistency index of $225 \pm 5 \mathrm{~mm} ; \rho_{\text {lime }}, \rho_{\mathrm{p}}$ and $\rho_{c}$ correspond to the specific gravity of lime, pozzolanic material (red mud) and cement, respectively.

Cylindrical specimens $(50 \mathrm{~mm}$ in diameter $\times 100 \mathrm{~mm}$ long $)$ were molded. Samples containing lime were kept in their molds for seven days, the first 24 hours at room temperature and the subsequent six
Table 1. Proportions of materials required for molding test specimens to determine the pozzolanic activity index according to the Brazilian NBR 5751 and 5752 standards.

\begin{tabular}{|c|c|c|c|}
\hline \multirow{2}{*}{ Material } & \multirow[t]{2}{*}{ NBR 5751} & \multicolumn{2}{|c|}{ NBR 5752} \\
\hline & & Mortar "A" & Mortar "B" \\
\hline Portland cement & - & 1.0 & 0.65 \\
\hline Pozzolanic material & $2 \times \frac{\rho_{P}}{\rho_{\text {lime }}}$ & - & $0,35 \times \frac{\rho_{P}}{\rho_{C}}$ \\
\hline Normal sand* & 9.0 & 3.0 & 3.0 \\
\hline Lime & 1.0 & - & - \\
\hline Water & $\mathrm{w}$ & $\mathrm{x}$ & $\mathrm{y}$ \\
\hline
\end{tabular}

* The sand must meet the requirements of the Brazilian NBR 7214 standard (Standard sand for cement testing).

days at $55 \pm 2{ }^{\circ} \mathrm{C}$. The specimens were demolded four hours prior to testing. Cement-based specimens (mortars "A" and "B") were left in airtight containers for 27 days and then tested by axial compression.

The samples' axial compressive strength was measured in an Instron 5500R universal testing machine under a load of $1.5 \mathrm{~mm} / \mathrm{min}$, according to the Brazilian standard NBR 7222 (Mortar and concrete - Determination of the mechanical strength of cylindrical specimens - Test method). A minimum of five samples per composition were tested. Samples showing standard deviations of over $5 \%$ were discarded and replaced with new samples for testing.

As a complement, the pozzolanic properties of the red mud were evaluated by chemical tests, according to the European EN 196-5 standard (Pozzolanicity test for pozzolanic cement). According to this standard, the pozzolanic index is determined by comparing the amount of calcium hydroxide in the aqueous solution which is in contact with the hydrated sample after a given period of time against that required to saturate the environment with a similar alkalinity. The test is considered positive if the calcium hydroxide concentration in solution is lower than the saturation concentration.

A mixture of $20 \mathrm{~g}$ of cement to $100 \mathrm{~mL}$ of distilled water was used as the standard. The mixture with red mud under evaluation contained $15 \mathrm{~g}$ of cement and $5 \mathrm{~g} \mathrm{RM}$ per $100 \mathrm{~mL}$ of distilled water. These mixtures ( 2 replicates for each test) were left in a climate chamber $\left(40 \pm 2{ }^{\circ} \mathrm{C} ; \mathrm{RH}=60 \%\right)$ for 14 days.

\section{Results and Discussion}

\subsection{Materials characterization}

The Portland cement used in this work has a specific surface area $0.93 \mathrm{~m}^{2} . \mathrm{g}^{-1}$ and its specific gravity is $3.11 \mathrm{~kg} . \mathrm{dm}^{-3}$. Its chemical composition is given in Table 2, while Figure 1 shows the XRD pattern. Common calcium silicates (alite and belite) are easily identified, while aluminates are present in minor amounts.

The sand has a specific surface area of $0.68 \mathrm{~m}^{2} \cdot \mathrm{g}^{-1}$ and its specific gravity is $2.70 \mathrm{~kg} \cdot \mathrm{dm}^{-3}$. The grain size distribution and chemical composition are given in Figure 2 and Table 3, respectively. According to the Brazilian NBR 7211 standard, it is classified as fine sand.

The red mud was received in the form of a paste containing about $40 \%$ free water. In the present study, the material was dried and crushed, and then used as a powdered additive. Ideally, if its potential as a constituent of mortar is confirmed, red mud should be incorporated and tested in the as-received condition, and the free water present in the mud should be considered a component of the mortar mix. 
Table 2. Chemical composition of ordinary CP-II 32 Z Portland cement (OPC).

\begin{tabular}{cccccccccc}
\hline Component & $\mathrm{CaO}$ & $\mathrm{SiO}_{2}$ & $\mathrm{Al}_{2} \mathrm{O}_{3}$ & $\mathrm{MgO}$ & $\mathrm{Fe}_{2} \mathrm{O}_{3}$ & $\mathrm{SO}_{3}$ & $\mathrm{~K}_{2} \mathrm{O}$ & $\mathrm{Na}_{2} \mathrm{O}$ & $\mathrm{LOI}^{*}$ \\
\hline Content $(\%)$ & 56.0 & 24.5 & 6.1 & 4.0 & 2.5 & 1.8 & 0.25 & 0.45 & 4.1 \\
\hline
\end{tabular}

$*$ LOI $=$ loss on ignition.

Table 3. Equivalent mineral oxide composition of the sand used in the mortars.

\begin{tabular}{ccccccccc}
\hline Component & $\mathrm{SiO}_{2}$ & $\mathrm{Al}_{2} \mathrm{O}_{3}$ & $\mathrm{Fe}_{2} \mathrm{O}_{3}$ & $\mathrm{CaO}$ & $\mathrm{Na}_{2} \mathrm{O}$ & $\mathrm{K}_{2} \mathrm{O}$ & $\mathrm{TiO}_{2}$ & $\mathrm{LOI}^{*}$ \\
\hline Content $(\%)$ & 95.33 & 1.91 & 0.64 & 0.20 & 0.15 & 0.91 & 0.32 & 0.47 \\
\hline
\end{tabular}

* LOI $=$ loss on ignition.

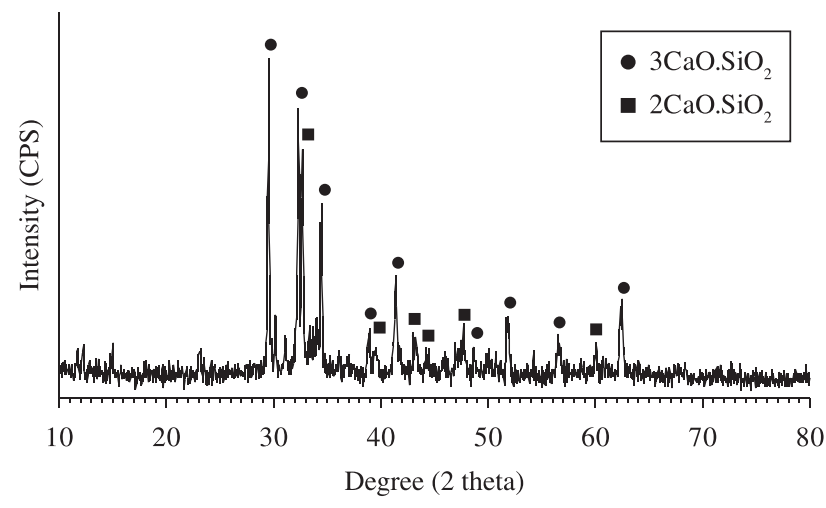

Figure 1. X-ray diffraction pattern of the Portland cement.

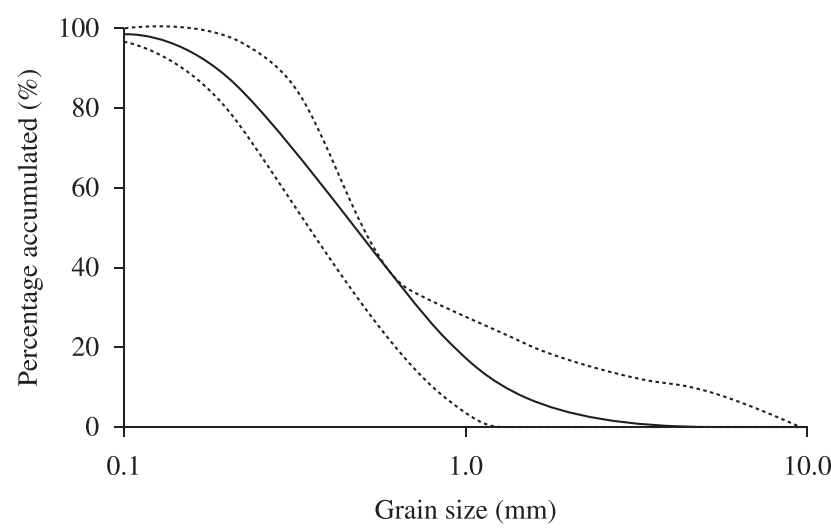

Figure 2. Particle size distribution of the sand, estimated by sieving.

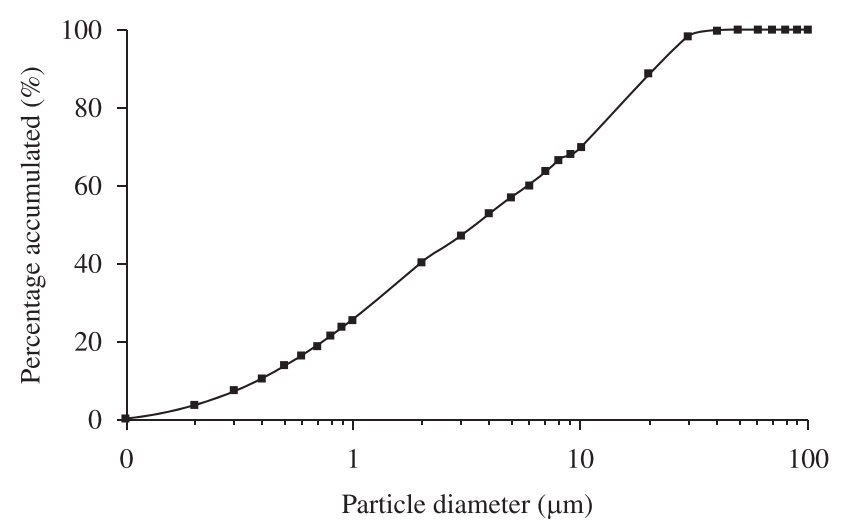

Figure 3. Particle size distribution of the dried red mud.
The specific surface area of bauxite waste is $20.27 \mathrm{~m}^{2} . \mathrm{g}^{-1}$, as indicated by the particle fineness illustrated in Figure 3. Its maximum particle size is under $40 \mu \mathrm{m}$ and the mean value is only about $8 \mu \mathrm{m}$. The specific gravity is $2.90 \mathrm{~kg} \cdot \mathrm{dm}^{-3}$ and the $\mathrm{pH}$ is very high (12.95), exceeding the limit (12.5) for non-hazardous wastes established by the Brazilian NBR 10004 standard. Table 4 gives the chemical composition of the waste, while Figure 4 shows the corresponding XRD pattern. As expected, alumina and iron oxide are the predominant components, but the relative amounts of $\mathrm{SiO}_{2}$ and $\mathrm{Na}_{2} \mathrm{O}$ (or $\mathrm{NaOH}$ ) are also relevant. Some of these oxides were also detected by XRD, in addition to aluminum hydroxide and a complex $\mathrm{Na}_{5} \mathrm{Al}_{3} \mathrm{CSi}_{3} \mathrm{O}_{15}$ phase.

The SEM micrographs show the complex microstructure of the red mud (Figure 5). The particles are flaky-shaped and agglomerates of about $1 \mu \mathrm{m}$ are visible, which are characteristic results of the crushing and milling operations. Once properly dispersed, the particles are very fine and appear to mix easily with cement to produce homogeneous batches.

\subsection{Effects on properties}

\subsubsection{Setting time}

The effect of the addition of the waste material on the setting time of mixtures was verified in two distinct conditions: (i) in formulations prepared with a fixed water content $(w / b=0.53$, "normal consistency", where b indicates cement or cement + mud) and (ii) adjusting (changing) the relative amount of water as a function of the Portland cement content replaced by red mud in order to adjust the consistency of the paste. Figures 6 and 7 show the results obtained in both conditions.

The addition of red mud tended to accelerate the setting process. The setting time changed from 345 minutes in mortars without red mud to 300 minutes in mortars containing $20 \%$ of waste. This effect may be explained by the presence of aluminum hydroxide in the mud, and also by its high alkalinity. Due to their fineness, the waste particles may also be partially responsible for retaining water, thus competing with cement. Since the water content was constant in all the formulations, the remaining free portion available for combination with cement particles was consumed rapidly.

When the relative amount of water was increased to ensure equal consistency of mixtures containing higher mud contents (Figure 7), the hardening process was naturally decelerated simply because mortars with a larger relative amount of red mud were prepared with more water. The setting time was delayed from 345 minutes (no red mud) to 485 minutes in mortars containing $20 \%$ mud. This behavior can be explained by the larger amount of water added, which varied by about $12 \%$ (165 to $187 \mathrm{~g}$ ). 


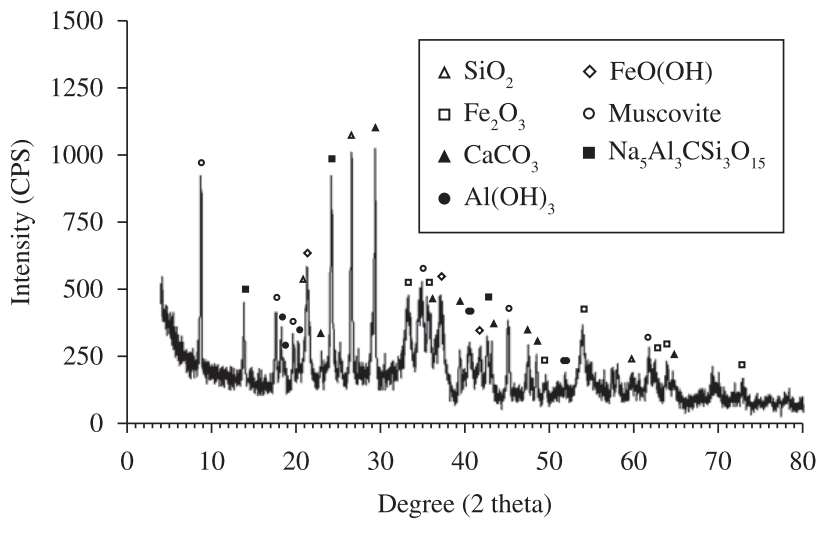

Figure 4. X-ray diffraction (XRD) pattern of dried red mud.
This increased amount of water ensures there is enough to wet the aluminum-rich compounds present in the mud, making the presence of the higher amount of alkalis (sodium, calcium and potassium compounds) more effective. These elements, which are highly insoluble (especially calcium compounds), form easily around the hydration particles of cement. This dense and insoluble envelope considerably reduces hydration by retarding the ionization rate, thus causing the phenomenon of slow hardening of the paste ${ }^{22}$.

\subsubsection{Pozzolanic activity}

The Brazilian NBR 12653 standard establishes the chemical and physical parameters required for a potential pozzolanic material, in addition to the estimated pozzolanic activity index (Table 5). All these requirements must be satisfied.

Table 4. Chemical composition of red mud estimated by XRF.

\begin{tabular}{cccccccccccccc}
\hline Component & $\mathrm{Al}_{2} \mathrm{O}_{3}$ & $\mathrm{Fe}_{2} \mathrm{O}_{3}$ & $\mathrm{Na}_{2} \mathrm{O}$ & $\mathrm{CaO}$ & $\mathrm{SiO}_{2}$ & $\mathrm{~K}_{2} \mathrm{O}$ & $\mathrm{MnO}$ & $\mathrm{TiO}$ \\
\hline Content $(\%)$ & 19.87 & 19.85 & 7.35 & 4.61 & 14.34 & 1.87 & 0.21 & 2.66 & 1.01 & 27.20 \\
\hline
\end{tabular}

* LOI = loss on ignition.
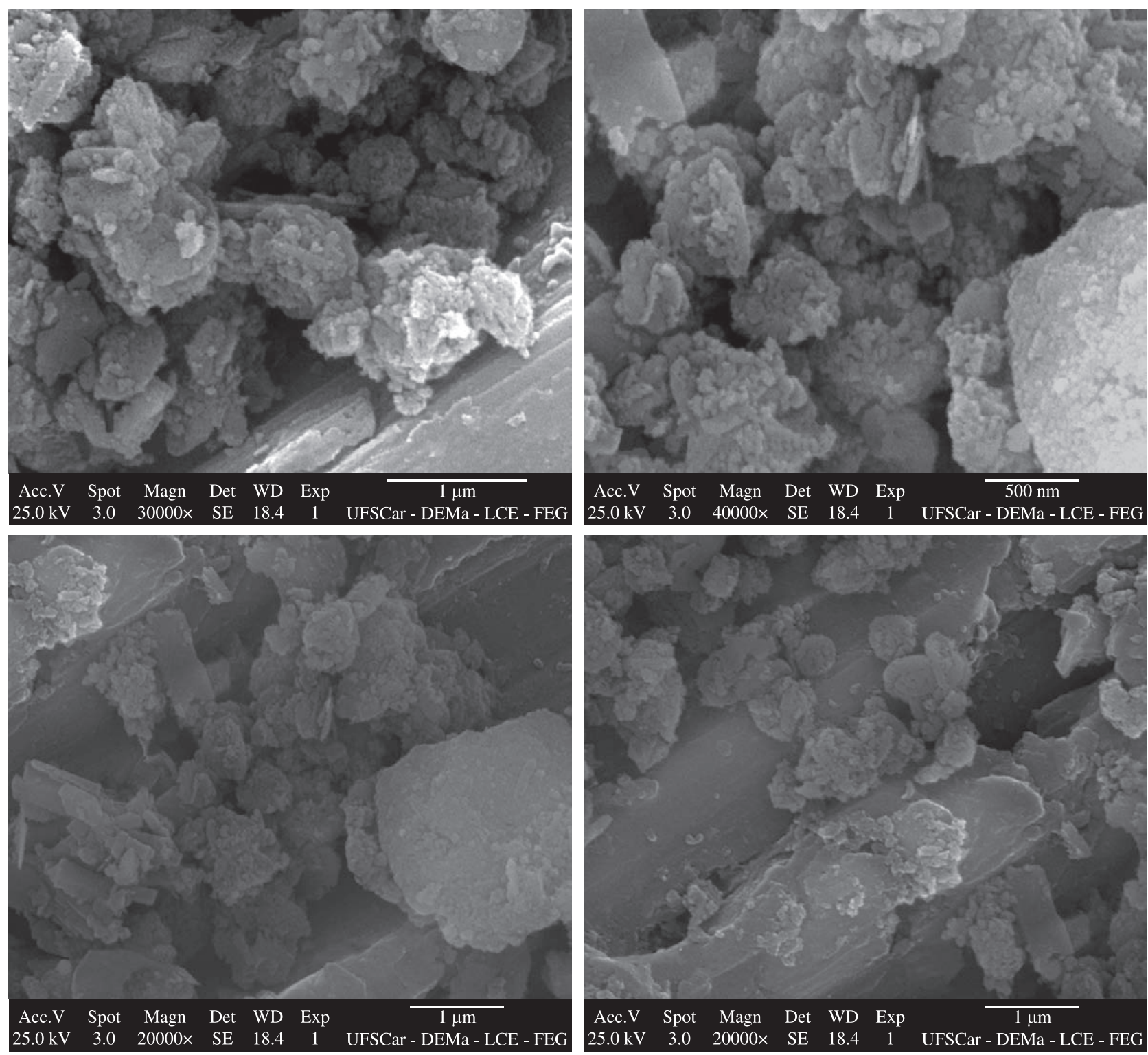

Figure 5. SEM micrographs of dried and crushed red mud. 


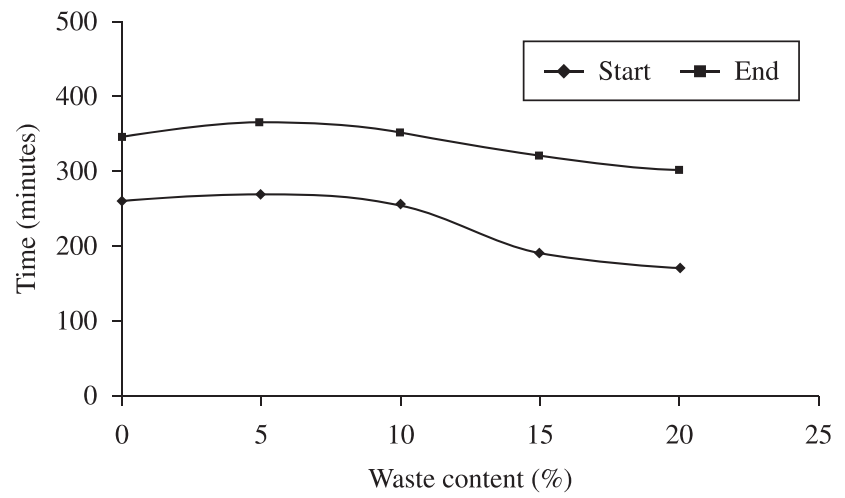

Figure 6. Setting time of Portland cement pastes as a function of red mud content, estimated for mixtures containing a fixed amount of water.

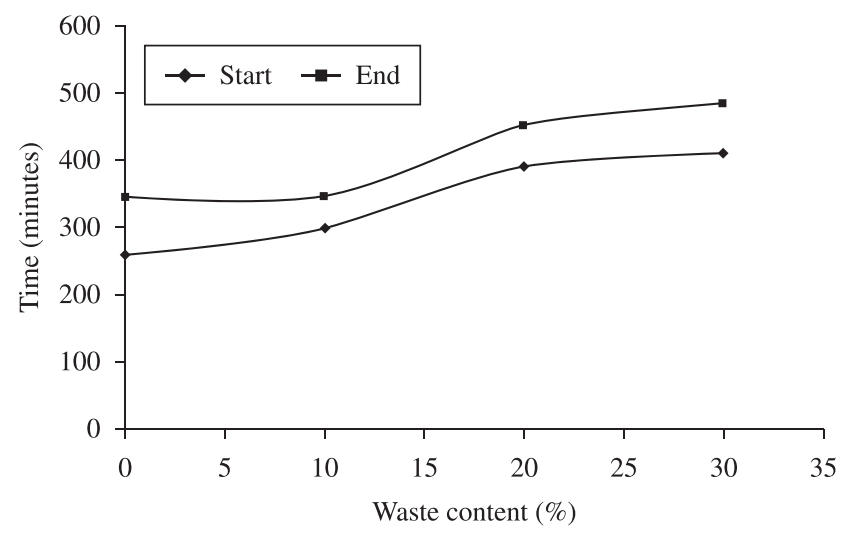

Figure 7. Change of setting time of Portland cement pastes as a function of red mud content for mixtures prepared with variable amounts of water needed to adjust the paste's consistency in the fresh state.

Table 5. Chemical and physical requirements of an artificial pozzolanic material (Class E) and estimated activity indices defined according to the Brazilian standard NBR 12653.

\begin{tabular}{lcc}
\hline \multicolumn{1}{c}{ Properties } & $\begin{array}{c}\text { Value } \\
\text { obtained }\end{array}$ & $\begin{array}{c}\text { Specification } \\
\text { NBR 12653 }\end{array}$ \\
\hline Chemical Requirements (wt. (\%)) & & \\
$\mathrm{SiO}_{2}+\mathrm{Al}_{2} \mathrm{O}_{3}+\mathrm{Fe}_{2} \mathrm{O}_{3}$ & 54.06 & $\geq 50$ \\
$\mathrm{SiO}_{3}$ & 0.17 & $\leq 4$ \\
$\mathrm{Humidity}$ content & 1.70 & $\leq 3 \%$ \\
Available alkalis (in $\left.\mathrm{Na}_{2} \mathrm{O}\right)$ & 0.15 & $\leq 1.5$ \\
Loss of ignition & 27.20 & $\leq 6 \%$ \\
\hline $\begin{array}{l}\text { Physical Requirements } \\
\text { Material retained (wt. (\%)) in a 45 } \mu \mathrm{m} \text { sieve }\end{array}$ & 32.15 & $\leq 34$ \\
$\begin{array}{l}\text { Compressive strength }(\mathrm{MPa}) \text { after } 7 \text { days } \\
\text { of curing (pozzolan with cement) }\end{array}$ & 16.62 & - \\
$\begin{array}{l}\text { Compressive strength }(\mathrm{MPa}) \text { after } 7 \text { days } \\
\text { of curing (pozzolan with lime) }\end{array}$ & $<1.0$ & $\geq 6 \mathrm{MPa}$ \\
$\begin{array}{l}\text { Compressive strength (MPa) after } 28 \text { days } \\
\text { of curing (cement), } \mathrm{R}_{\mathrm{CA}}\end{array}$ & 24.95 & - \\
$\begin{array}{l}\text { Compressive strength (MPa) after } 28 \text { days of } \\
\text { curing (pozzolan with cement), } \mathrm{R}_{\mathrm{CB}}\end{array}$ & 19.61 & - \\
$\begin{array}{l}\text { Pozzolanic activity index, } \mathrm{I}_{\mathrm{PA}}=\mathrm{R}_{\mathrm{CB}} / \mathrm{R}_{\mathrm{CA}} \\
\text { Water required, } \mathrm{H}_{2} \mathrm{O}_{\text {req }}\end{array}$ & 0.79 & $\geq 0.75$ \\
\hline & 1.13 & $\leq 1.15$ \\
\hline
\end{tabular}

The pozzolanic activity index $\left(\mathrm{I}_{\mathrm{PA}}\right)$ for samples containing Portland cement is defined by Equation 1. $\mathrm{R}_{\mathrm{CB}}$ is the mechanical strength of mortar " $\mathrm{B}$ " while $\mathrm{R}_{\mathrm{CA}}$ is the average value estimated for mortar "A", tested after 28 days of curing.

$$
I_{P A}(\%)=100 \times \frac{R_{C B}}{R_{C A}}
$$

$\mathrm{H}_{2} \mathrm{O}_{\text {req }}$ corresponds to the relative amount of water required to produce mortars with a consistency of $225 \pm 5 \mathrm{~mm}$ in the flow table, as given by Equation 2:

$$
\mathrm{H}_{2} \mathrm{O}_{\text {req. }}(\%)=100 \times \frac{y}{x}
$$

Since the waste material was dried and crushed before testing, the results correspond only to this situation. According to Table 5, the waste cannot be considered a purely pozzolanic material, since some requirements are not satisfied (e.g., loss of ignition, mechanical strength after 7 days of curing of lime-containing samples). However, there are promising indications of the material's potential to partially replace cement for less demanding (secondary) applications.

It is generally accepted that the cementitious activity of minerals depends mainly on the active $\mathrm{SiO}_{2}$ and $\mathrm{Al}_{2} \mathrm{O}_{3}$ contents. Thus, the quantity of $\mathrm{SiO}_{2}$ and $\mathrm{Al}_{2} \mathrm{O}_{3}$ dissolved in $\mathrm{NaOH}$ solution can be used to evaluate the cement's pozzolanic activity ${ }^{23}$.

The effect of a single component such as red mud is difficult to evaluate simply by determining the mechanical strength of mortars. The European NP EN 196-5 standard compares the quantity of calcium hydroxide present in the aqueous solution in contact with hydrated cement after 14 days against the amount of calcium hydroxide required to saturate the environment of equal alkalinity. The material is considered pozzolanic if the calcium hydroxide concentration in solution is lower than the saturation concentration. The results are shown in Figure 8.

The pozzolanic effect is denoted by a decrease in the $\mathrm{CaO}$ concentration of the liquid phase, since calcium hydroxide generated by cement hydration is sequestered and combined by the pozzolan. There is a decrease in the $\mathrm{CaO}$ concentration of the solution when red mud is added and a simultaneous increase in the $\left[\mathrm{OH}^{-}\right]$ion concentration. When fresh (untreated) red mud was used, the values approached the saturation limit.

The cement appears above the saturation limit on the calcium oxide curve because the cement itself is not pozzolanic. The addition of pozzolan in the presence of water will adjust the calcium hydroxide from the cement hydration, lowering the calcium oxide content in the liquid phase of cement paste and pozzolan. This fact is proven by the results shown in Figure 8, which shows a decrease in $\mathrm{CaO}$ content in response to the addition of pozzolan.

This result confirms the physical analysis of pozzolanicity, showing that red mud presents results very close to the limit of standards and can be considered satisfactory for the partial replacement of cement in secondary construction applications. However, red mud cannot be considered a perfectly pozzolanic material.

Pera et al. ${ }^{20}$ used an algebraic method to determine the pozzolanic activity index (Feret's equation). The results of the physical and chemical analyses in the present work are similar to those reported by Pera et al. ${ }^{20}$, i.e., samples containing red mud showed slightly lower pozzolanicity than the reference samples. 


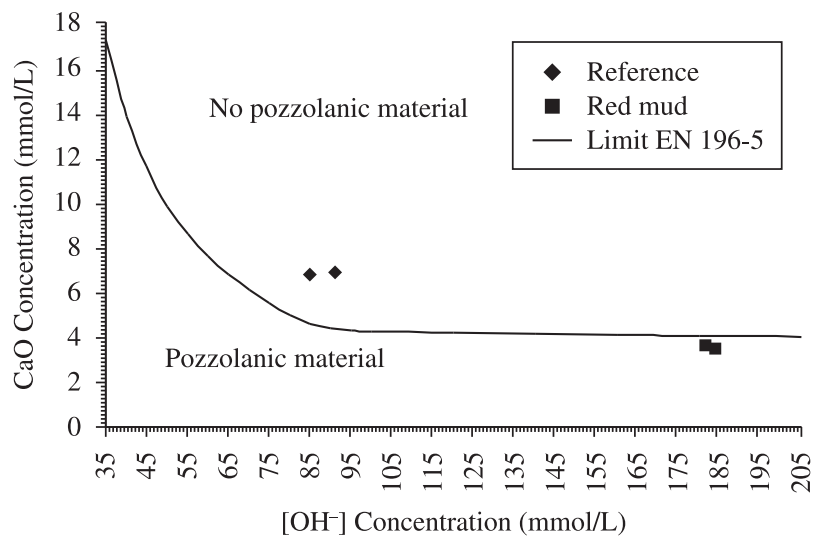

Figure 8. Diagram for determining pozzolanicity according to NP EN 196-5 standard.

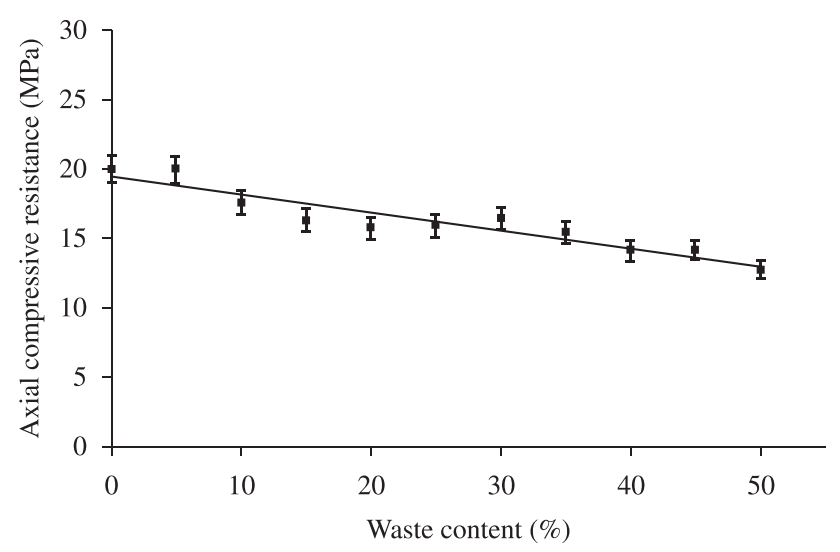

Figure 9. Axial compressive strength of mortars (28 days of curing) as a function of red mud content substituting Portland cement.

\subsubsection{Mechanical strength}

Mechanical properties are holistic indicators of the microstructural development of cement matrices in response to hydration. In addition to chemical effects, values are controlled mainly by physical parameters such as porosity and compactness. The grain size distribution of components and the water/binder ratio are therefore relevant parameters that control the workability of the mixtures in the fresh state, with obvious effects on the mechanical strength of hardened bodies.

Figure 9 shows the evolution of compressive strength of samples estimated after 28 days of curing and containing increasing amounts of red mud replacing Portland cement in the mixture. As expected, the mechanical strength diminished with increasing levels of cement replacement, since red mud has limited hydraulic characteristics. This decrease was almost linear and the strength of mortar prepared with a maximum relative amount of mud (50\% substitution of cement) was about $64 \%$ that of the reference sample (12.75 vs. $20.1 \mathrm{MPa}$, respectively).

Other authors ${ }^{10,20}$ have obtained satisfactory results with increased mechanical strength with pastes and mortars containing red mud. However, these studies fail to identify the reasons leading to this behavior. The high fineness of red mud (filler effect), allied to the reasonable pozzolanic activity mentioned earlier, are probably the determining factors for these good results.
According to Pinnock and Gordon ${ }^{24}$ and Majumdar et al. ${ }^{25}$, calcium oxide reacts with the alumina in red mud to produce calcium aluminates $\left(\mathrm{CA}\right.$, and possibly $\mathrm{C}_{5} \mathrm{~A}_{3}$ ). Calcium oxide also hydrates to produce cementitious compounds in reactions that are well known to be responsible for the strength of cement mortars with high alumina content. Delagrave et al. apud Pruckner and Gjørv ${ }^{26}$ showed that the compressive strength of cementitious matrices increases with a higher concentration of sodium hydroxide (which is abundant in red mud).

The formulation prepared to determine the pozzolanic index (cement replacement of 35 wt. (\%)) showed a $23 \%$ decrease in mechanical strength. This value is consistent with the estimated $\mathrm{R}_{\mathrm{CB}} / \mathrm{R}_{\mathrm{CA}}$ ratio (0.79). These results confirm the feasibility of using red mud as a substitute for Portland cement in mortars used for non-demanding structural applications and secondary construction activities.

\section{Conclusions}

Tests performed in this study suggest that non-calcined red mud is an interesting candidate for use in mortars and concretes for nonstructural applications, partially replacing the cement in the mixture.

Formulations prepared with a fixed amount of mixing water and with increasing amounts of red mud tend to set quickly due to the fineness of the waste material and its composition (aluminum-rich).

Red mud cannot be considered strictly an artificial pozzolan since it does not meet some requirements. This applies particularly to the mechanical strength of mixtures containing lime after 7 days of curing, which is below the standard required value. However, its pozzolanic activity index $\left(\mathrm{I}_{\mathrm{PA}}\right)$ is good. More tests are needed to reach conclusions about the pozzolanic activity of untreated red mud. The $36 \%$ loss in compressive strength (in formulations containing $50 \%$ of natural waste) may indicate a certain degree of pozzolanic activity of red mud associated with the influence of the filler effect.

The mechanical strength diminishes with increasing proportions of red mud in place of cement, but mortars prepared with a $50 \%$ substitution still show suitable strength for non-structural applications. The red mud recycling alternative proposed here appears to be technologically viable.

\section{Acknowledgements}

The authors wish to thank CNPq - National Council for Scientific and Technological Development (Brazil), PPGCEM/UFSCar Postgraduate Program in Materials Science and Engineering at the Federal University of São Carlos (Brazil), and UA/DECV Department of Ceramics and Glass Engineering, University of Aveiro \& CICECO (Portugal) - Project FCT-PTDC/CTM/65243/ 2006, for their support of this research.

This project was not funded by Alcoa Brazil.

\section{References}

1. Raupp-Pereira F, Silva L, Segadães AM, Paiva H and Labrincha JA. Effects of potable water filtration sludge on the rheological behaviour of one-coat plastering mortars. Journal of Materials Processing Technology. 2007; 190(1-3):12-17.

2. Dondi M, Marsigli M and Fabbri B. Recycling of industrial and urban wastes in brick production: a review. Tile Brick International. 1997; 13(4):302-8.

3. Raupp-Pereira F, Silva L, Hotza D, Segadães AM, Labrincha JA. Potable water filtration sludge: use as workability-aid in one-coat plastering mortars. Construction and Building Materials. 2007; 21(3):646-653.

4. Brazilian Aluminum Association - ABAL. O alumínio: aluminio primário. Available from: <www.abal.org.br/aluminio/producao/alupri.asp>. Access in: 13/05/2010. 
5. Pascoal C and Pandolfelli VC. Refractory bauxites: chemical composition, phases and properties - Part I. Cerâmica. 2000; 46:76-82.

6. Brazilian Mining Association - IBRAM. Bauxita. Available from: $<$ http://www.ibram.org.br/sites/1300/1382/00000033.pdf>. Access in: 15/05/2010

7. Roskill Reports. The economics of bauxite \& alumina. Available from: $<\mathrm{http}: / /$ www.roskill.co.uk/index.html >. Access in: 8/06/2010.

8. Glasser FP. Fundamental aspects of cement solidification and stabilization. Journal of Hazardous Materials. 1997; 52(2-3):151-170.

9. Singh M, Upadhayay SN and Prasad PM. Preparation of special cements from red mud. Waste Management. 1996; 16(8):665-670.

10. Ribeiro DV, Labrincha JA and Morelli MR. Use of red mud as addition for portland cement mortars. Journal of Materials Science and Engineering. 2010; 4(8):1-9.

11. Amritphale SS, Anshula A, Chandraa N and Ramakrishnana N. A novel process for making radiopaque materials using bauxite Red mud. Journal of European Ceramic Society. 2007; 27(4):1945-1951.

12. Amritphale SS and Patel M. Utilization of red mud, fly ash for manufacturing bricks with pyrophyllite. Silicates Industriels. 1987; 52(3-4):31-35.

13. Gordon JN, Pinnock WR and Moore MM. A preliminary investigation of strength development in Jamaican red mud composites. Cement and Concrete Composites. 1996; 18(6):371-379.

14. Vincenzo MS, Renz C, Stefano M and Giovanni C. Bauxite red mud in the ceramic industry. Part 2: production of clay based ceramics. Journal of European Ceramic Society. 2000; 20(3):245-252.

15. Yalcin $\mathrm{N}$ and Sevnic V. Utilization of bauxite waste in ceramic glazes. Ceramic International. 2000; 26(5):485-493.
16. Singh M, Upadhayay SN and Prasad PM. Preparation of iron rich cements using red mud. Cement and Concrete Research. 1997; 27(7):1037-1046.

17. Dow C and Glasser FP. Alkali releases from crushed minerals and thermally activated constituents of metakaolin. Advances in Cement Research. 2003; 15(4):137-143.

18. Yogananda MR and Jagadish KS. Pozzolanic properties of rice husk ash, burnt clay and red mud. Building and Environment. 1988; 23(4):303-308.

19. Cook DJ, Pama RP and Paul BK. Rice husk ash-lime-cement mixes for use in masonry units. Building and Environment. 1977; 12(4):281-288.

20. Pera J, Boumaza R and Ambroise J. Development of a pozzolanic pigment from red mud. Cement and Concrete Research. 1997; 27(10):1513-1522.

21. Mehta PK and Monteiro PJM. Concrete: structure, properties and materials. California: Prentice Hall; 1994. 249 p.

22. Silva, ART. Avaliação da resistência Mecânica de argamassas de cimento Portland contendo serragem de couro tratada em meio ácido. [Master thesis]. São Carlos (Brazil), Federal University of São Carlos (UFSCar); 2006.

23. Tsakirids PE, Agatzini-Leonardou S and Oustadakis P. Red mud addition in the raw meal for the production of Portland cement clinker. Journal of Hazardous Materials. 2004; B116:103-110.

24. Pinnock WR and Gordon JN. Assessment of strength development in Bayer process residues. Journal of Material Science. 1992; 27(3):692-696.

25. Majumdar AJ, Singh B and Edmonds RN. Hydration of mixtures of cement aluminous cement and granulated blast furnace slag. Cement and Concrete Research. 1990; 20(2):197-208.

26. Pruckner $\mathrm{F}$ and Gjørv OE. Effect of $\mathrm{CaCl}_{2}$ and $\mathrm{NaCl}$ additions on concrete corrosivity. Cement and Concrete Research. 2004; 34(7):1209-1217. 